Klin. Wschr. 52, 419-425 (1974)

(C) by Springer-Verlag 1974

\title{
Originalien
}

\section{Elevated Plasma Histamine Concentrations in Surgery: Causes and Clinical Significance*}

\author{
W. Lorenz, W. Seidel, A. Doenicke, R. Tauber, H.-J. Reimann, R. Uhlig, G. Mann, P. Dormann, \\ A. Schmal, G. Häfner, and H. Hamelmann
}

Division of Experimental Surgery and Pathological Biochemistry and Surgical Clinic of the University, Marburg/Lahn, and Division of Anaesthesiology, Surgical Outpatient Clinic of the University, Munich, Federal Republic of Germany

Summary. Histamine concentrations in plasma, whole blood and various tissues of human subjects, monkeys, pigs and dogs were determined by fluorometric methods before, during and after surgical operations. Following intraabdominal surgery in 6 of 22 patients elevated plasma histamine levels were found several hours after the end of operation. Some of the causes of histamine release in surgery were found to be premedication by atropine, intravenously administered anaesthetics, infusion of plasma substitutes and manipulation on the gut. Acute blood losses were without effect on the plasma histamine levels. Clinical symptoms and pathophysiological reactions, such as tachycardia, hypotension, increased gastric secretion and anaphylactoid reactions could be related to the release of histamine in some circumstances.

Key words: Plasma histamine, operations, anaesthesia, plasma substitutes, acute gastro intestinal ulcers.
Erhöhte Plasmahistaminspiegel bei chirurgischen Eingriffen: Ursachen und klinische Bedeutung.

Zusammenfassung. Histaminkonzentrationen in Plasma, Vollblut und verschiedenen Geweben von Mensch, Affe, Schwein und Hund wurden vor, während und nach Operationen mit fluorometrischen Methoden gemessen. Nach intraabdominellen Eingriffen wurden bei 6 von 22 Patienten erhöhte Plasmahistaminspiegel noch Stunden nach der Operation gefunden.

Als Ursachen der Histaminfreisetzung bei Operationen wurden nachgewiesen: Prämedikation durch Atropin, Anästhesieeinleitung mit intravenös verabreichten Kurznarkotika, Infusion von Plasmasubstituten und Manipulationen am Darm. Akuter Blutverlust war ohne Einfluß auf die Plasmahistaminspiegel. Klinische Symptome und pathophysiologische Reaktionen, wie Tachykardie, arterielle Hypotension, erhöhte Magensekretion und anaphylaktoide Reaktionen konnten auf Histaminfreisetzung unter bestimmten Umständen zurückgeführt werden.

Schlüsselwörter: Plasmahistaminspiegel, Operationen, Narkose, Blutersatzmittel, Streßulcus.

Vasoactive biogenic amines, such as histamine, serotonin and the catecholamines, are ubiquitously distributed in the tissues of nearly all vertebrates investigated so far (Lorenz et al., 1973). Many workers have shown their release or increased formation in local processes, like inflammation, ischaemia or trauma. They are also liberated in general reactions, such as shock and anaphylaxis [for a survey see Rocha e Silva (1955), Schayer (1961), Erspamer (1966), Holtz and Palm (1966)]. However, the clinical significance of these tissue hormones, especially in the case of histamine and serotonin, remains largely unknown.

During operations in human subjects and in laboratory animals, reactions occur which might be due to a release of histamine-for example suddenly developing hypotensive reactions, increase of bronchial resistence with bronchospasm, vomiting of strongly acid gastric juice despite preceding fasting and development of postoperative stress ulcers. In this study, the appearance of free, pharmacologically-active histamine in the plasma has been determined before, during and after operations in patients and in experimental animals. Causes of such a histamine release have been evaluated and their clinical significance

\footnotetext{
*Supported by a grant of Deutsche Forschungsgemeinschaft (Lo 199/3).
} plasma histamine concentration under such circumstances with that observed following the infusion of histamine in various biologically-effective doses.

\section{Materials and Methods$$
\text { Materials }
$$

Normal human tissues (examined by histology) were obtained from 93 patients (both sexes, $52-87 \mathrm{~kg}$, aging from 20 to 54 years) during various operations (anaesthesia by thiopentone, suxamethonium, Alloferin ${ }^{\circledR}$, fluothane-nitrous oxide). Tissues from animals were withdrawn from 6 monkeys ${ }^{1}$ (Macaca actoides, both sexes, 7-12 kg), anaesthesized by Parkesernyl, 5 adult pigs (German landrace, femal, 100$150 \mathrm{~kg}$ ), and 7 adult mongrel dogs (both sexes, 21-38 kg) anaesthesized by pentobarbitone $(15-20 \mathrm{mg} / \mathrm{kg}$ i.v. $)$. The tissues were frozen immediately after withdrawal by $\mathrm{CO}_{2}$ snow and kept for maximum 4 weeks in a deep-freeze before testing their histamine content.

Blood for the determination of histamine in plasma and whole blood was collected and prepared according to the method of Lorenz et al. (1972 b). It was obtained from 22 patients (see Table 2) and 104 test persons (male students, 57-94 kg, 22-28 years old, healthy by case history), as well as from 6 monkeys (see above), 16 young pigs (both sexes, $25-34 \mathrm{~kg}$ ), and 42 adult mongrel dogs (both sexes, 14-36 kg) following fasting for at least 12 hours.

1 We thank very much the Behringwerke, Marburg, for the generous gift of the animals. assessed by means of comparing the increase of the 
Drugs and Reagents. Thiopentone (Abbott), propanidid (Bayer), methohexitone (Lilly), Althesin CT 1341 ${ }^{\circledR}$ (Glaxo), Etomidate ${ }^{\circledR}$ (Janssen), pentobarbitone (Abbott), Parke ${ }^{\circledR}$ (Parke and Davis), fluothane (Rheinpharma), suxamethonium (Lentia), Alloferin ${ }^{\circledR}$ (Roche), atropine (university's pharmacy), pethidin (Hoechst), heparin for biochemical research (180 I.U.) mg, Roche), dextran-60 (Makrodex ${ }^{\circledR}$, Knoll, batches No. K 169 and 3262/A 3), gelatin (Haemaccel ${ }^{\circledR}$, Behringwerke, batches No. 2551 in human subjects, No. 2406, 2551, 2559, 3000 and $V 183 / \mathrm{I}$ in dogs, and No. 3000 and $V 183 / \mathrm{I}$ in monkeys), Ringer's solution (pH 6.0, university's pharmacy).

Reagents were employed according to Lorenz et al. (1972 b). Only twice distilled water was used.

\section{Experimental Arrangements}

For a single determination of the plasma histamine concentration $19.5 \mathrm{ml}$ of blood were withdrawn from a cubital vein by a polyethylene syringe containing $2 \mathrm{mg}$ heparin dissolved in $0.5 \mathrm{ml}$ of physiological saline. In all experimental arrangements this procedure was identical, both in human subjects and in animals, but the time of collection of the blood samples was different:

\section{Operations in Human Subjects}

Blood was obtained immediately before and few minutes, 4,8 and $20 \mathrm{hrs}$. after operations (Table 2) which were all carried out by the same experienced surgeon (W.S.) under general anaesthesia as described in materials. For the determination of histamine in the whole blood, an additional $5 \mathrm{ml}$ of blood were withdrawn immediately after collecting the samples for the plasma histamine determination.

\section{Injection of Anaesthetic Drugs and Atropine in Healthy Test Persons}

Using the arrangements as described by Lorenz et al., 1972 , atropine $(0.01 \mathrm{mg} / \mathrm{kg}$ i.v. ) was injected $10 \mathrm{~min}$ before the administration of the hypnotics. Blood was collected before, and 1,5 and $10 \mathrm{~min}$ after giving atropine. Then methohexitone $(2.5 \mathrm{mg} / \mathrm{kg}$ in $60 \mathrm{sec}$ ), propanidid ( $5 \mathrm{mg} / \mathrm{kg}$ in $20 \mathrm{sec}$ ), Althesin CT 1341 (1) $(0.075 \mathrm{ml} / \mathrm{kg}$ in $60 \mathrm{sec})$, and Etomidate $(0.2 \mathrm{mg} / \mathrm{kg}$ in $20 \mathrm{sec}$ ) was injected and further blood samples were withdrawn at 1, 5, 10, 20 and $30 \mathrm{~min}$ following administration of the anaesthetic.

\section{Acute Blood Losses and Blood Replacement in Healthy Test Persons}

According to the technique of Messmer et al. (1970), $500 \mathrm{ml}$ of venous blood were obtained within about $3 \mathrm{~min}$ (ca. $2 \mathrm{ml} / \mathrm{kg}$ and $\mathrm{min}$ ) using an equipment for blood donation. The same volume of plasma substitutes $(500 \mathrm{ml}$ of dextran, gelatin, Ringer's solution, ca. $2 \mathrm{ml} / \mathrm{kg}$ and $\min , 37^{\circ} \mathrm{C}$ ) was infused under pressure 30 sec later. Blood was withdrawn for histamine assay before and after the blood donation as well as $1,5,10,20$ and $30 \mathrm{~min}$ following infusion of plasma substitutes.

\section{Acute Blood Losses and Infusion of Plasma Substitutes in Monkeys, Pigs and Dogs}

In anaesthesia as described under materials, according to the method of Messmer $e t a l$. (1970), $150-200 \mathrm{ml}$ of arterial blood in monkeys and $500 \mathrm{ml}$ in pigs and dogs was withdrawn within about $3 \mathrm{~min}$ via a catheter in the femoral artery $(6-7 \mathrm{ml} / \mathrm{kg}$ and $\mathrm{min})$. It was replaced in the same time as used for bleeding by the same volume of the plasma substitutes using a catheter in the $v$. cava inferior. Blood for histamine assay was withdrawn from the right atrium before and after bleeding, as well as 1, 5, 10 and 20 min following the pressure infusion.

\section{Anaesthesia and Operation Stress in Monkeys and Dogs}

Following anaesthesia as described in Materials, in 6 monkeys and 9 dogs catheters were inserted in the femoral vein and after laparotomy, in dogs also in the portal and hepatic veins. Blood for histamine assay was collected from the right atrium immediately after introduction of anaesthesia, $30 \mathrm{~min}$ later at the end of operation, and $30 \mathrm{~min}$ after the end of operation.

\section{Anaesthesia and Early Phase of Liver Transplantations in Pigs}

In 7 pigs, anaesthesia was introduced by pentobarbitone (15-25 mg/kg i.v.) and continued as described by Lorenz et al. (1972). Before and after laparotomy, splenectomy, applying a porta-caval by-pass and exposing the liver vessels according to Lorenz et al. (1972) blood for histamine assay was withdrawn from the right atrium via a catheter in a jugular vein.

\section{Melhods \\ 1. Determination of Histamine in Tissues, Whole Blood and Plasma}

Following precipitation of the proteins by perchloric acid histamine in all tissue extracts and whole blood as well as in the plasma of pigs was isolated by cation-exchange chromatography on Dowex $50 \mathrm{~W}-\mathrm{X} 8$ and determined fluorometrically after condensation with o-phthaldialdehyde according to Lorenz et al. (1971). Histamine in the plasma of human subjects, dogs and monkeys was isolated by ion-exchange chromatography on Dowex 50 and subsequent solvent partition according to Lorenz et al. (1972b). Histamine in tissues and whole blood was given in $\mu \mathrm{g}$ histamine dihydrochloride/g fresh weight or $\mathrm{ml}$, plasma histamine in $\mathrm{mg}$ histamine base $/ \mathrm{ml}$. Histamine release was considered only as significant, when plasma histamine levels higher than $1 \mathrm{ng} / \mathrm{ml}$ were reached.

\section{Determination of Arterial Blood Pressure and Heart Rate}

In human subjects, the blood pressure was determined by the sphygmomanometric method at 1 min intervals according to Lorenz et al., 1972. In monkeys and dogs, the systolic arterial blood pressure was measured via a catheter in the femoral artery by a Statham pressure transducer $\mathrm{P} 23 \mathrm{Db}$ and recorded by a Hellige compensograph, in pigs via a catheter in the carotid artery by the same experimental arrangement. The heart rate was determined with the aid of the ECG (lead II), (Lorenz et al., 1972).

\section{Determination of Gastric Acid Secretion in Test Persons}

$A$ Levin tube was inserted into the stomach and its position controlled by $\mathrm{X}$-rays. Gastric juice was collected during the same intervals as blood was taken for the plasma histamine determination. The acid output was measured by titration to $\mathrm{pH} 7.0$ using the glass electrode and expressed in meq $\mathrm{HCl} / \mathrm{min}$. For further details see Lorenz et al. (1972).

\section{Statislical Evaluation}

The results were statistically evaluated by means of the Student-t-test and the $t$-test on paired data.

\section{Results}

Histamine Concentrations in Tissues, Blood and Plasma in the Course of Operations

Histamine concentrations in human tissues and in those of laboratory animals frequently used in ex- 
Table 1. Histamine content of various tissues in man, monkeys, pigs and dogs

\begin{tabular}{|c|c|c|c|c|c|}
\hline \multirow[t]{2}{*}{ Tissue } & \multirow[t]{2}{*}{$n$} & \multicolumn{4}{|c|}{ Histamine content in $\mu \mathrm{g} / \mathrm{g}$ fresh weight } \\
\hline & & Man & $\begin{array}{l}\text { Monkey } \\
(n=6)\end{array}$ & $\begin{array}{l}\text { Pig } \\
(n=5)\end{array}$ & $\begin{array}{l}\operatorname{Dog} \\
(n=7)\end{array}$ \\
\hline \multicolumn{6}{|l|}{ Stomach } \\
\hline Fundus & 5 & $14.8+5.6$ & $82.6 \pm 43.5$ & $150.4 \pm 67$ & $101 \pm 15$ \\
\hline Corpus & 23 & $16.2 \pm 8.0$ & $97.0 \pm 55.3$ & $99.7 \pm 26.5$ & $117 \pm 40$ \\
\hline Antrum & 24 & $10.0 \pm 4.4$ & $59.9 \pm 33.4$ & $102 \pm 49$ & $69.3 \pm 24.7$ \\
\hline Duodenum & 3 & $10.4 \pm 8.2$ & $113 \pm 46$ & $140 \pm 13$ & $115 \pm 18$ \\
\hline Jejunum & 10 & $13.7 \pm 7.9$ & $138 \pm 75$ & $234 \pm 78$ & $145 \pm 26$ \\
\hline Ileum & 13 & $16.5 \pm 6.0$ & $70.7 \pm 36.3$ & $198 \pm 54$ & $83.4 \pm 16.8$ \\
\hline Appendix & 3 & $11.9 \pm 1.1$ & $37.1 \pm 10.3$ & $127 \pm 53$ & - \\
\hline Colon & 9 & $9.1 \pm 5.5$ & $51.0 \pm \quad 9.9$ & $109 \pm 23$ & $71.6 \pm 21.3$ \\
\hline Sigma & 16 & $7.6 \pm 3.8$ & - & - & - \\
\hline Rectum & 17 & $7.9 \pm 5.0$ & $41.2 \pm 15.4$ & $73.3 \pm 42.5$ & $31.2 \pm 8.8$ \\
\hline Liver & 33 & $3.9 \pm 2.6$ & $2.7 \pm \quad 1.7$ & $21.4 \pm 7.8$ & $38.3 \pm 16.0$ \\
\hline Spleen & 6 & $3.7 \pm 1.5$ & $3.3 \pm \quad 3.4$ & $44.8 \pm 5.4$ & $20.9 \pm 10.5$ \\
\hline Lungs & 10 & $22.7 \pm 17.1$ & $263 \pm 224$ & $222 \pm 35$ & $63.8 \pm 45.4$ \\
\hline Kidney & 3 & 1.80 .5 & $9.5 \pm \quad 8.1$ & $1.8 \pm 0.9$ & $1.1 \mp 0.8$ \\
\hline Abdominal skin & 3 & $5.3 \pm 3.8$ & $6.8 \pm \quad 4.4$ & $29.6 \pm 6.2$ & $18.5 \pm 7.0$ \\
\hline \multicolumn{6}{|l|}{ Muscle } \\
\hline (Rectus abdominis) & 7 & $1.8 \pm 0.8$ & 4.4 土 3.2 & $2.3 \pm 1.0$ & $1.9 \pm 0.8$ \\
\hline
\end{tabular}

Mean values + S.D. In man $n=$ number of organs tested, $1-3$ being obtained from the same subject. In animals $n=$ number of individuals tested. For further conditions see Materials and Methods.

Table 2. Plasma histamine concentrations in patients before and after various operations

\begin{tabular}{|c|c|c|c|c|c|c|c|c|c|}
\hline \multirow[t]{3}{*}{ No. } & \multirow{3}{*}{$\begin{array}{l}\text { Pat. } \\
\text { Name }\end{array}$} & \multirow[t]{3}{*}{ Sex } & \multirow{3}{*}{$\begin{array}{l}\text { Day of } \\
\text { oper- } \\
\text { ation }\end{array}$} & \multirow[t]{3}{*}{ Diagnosis/Operation } & \multicolumn{5}{|c|}{ Plasma histamine concentrations (ng/ml) } \\
\hline & & & & & \multirow{2}{*}{$\begin{array}{l}\text { Before } \\
\text { oper- } \\
\text { ation }\end{array}$} & \multicolumn{4}{|c|}{ After the end of the operation } \\
\hline & & & & & & $\begin{array}{l}\text { Few } \\
\text { minutes }\end{array}$ & 4 hrs & $8 \mathrm{hrs}$ & $20 \mathrm{hrs}$ \\
\hline 1 & Sch.H. & $\hat{\sigma}$ & $23 . \quad 2.72$ & $\begin{aligned} \text { Duodenal ulcer/select. vagotomy } \\
+ \text { pyloroplasty }\end{aligned}$ & 0.3 & 0.9 & 1.3 & 0.4 & 0.4 \\
\hline 2 & F.A. & $0^{x}$ & 2. 5.72 & Gastric ulcer $/ 2 / 3$ resection $+\mathrm{B}$ II & 0.5 & 0.8 & 0.4 & - & 0.4 \\
\hline$\overline{3}$ & B.M. & 号 & 23.6 .72 & Duodenal ulcer/select, vagotomy + B I & 0.5 & 0.8 & 0.8 & 0.5 & - \\
\hline 4 & G.K. & $\hat{0}$ & 4. 12.72 & $\begin{array}{c}\text { Stress ulcer/select. vagotomy+ } \\
\text { pyloroplasty }\end{array}$ & 0 & 1.5 & 0 & 0 & $--^{a}$ \\
\hline 5 & G.K. & q & 5.12 .72 & Gastric cancer/subtotal gastrectomy & 0 & 0.7 & 0 & - & 0 \\
\hline 6 & L.A. & $\hat{0}$ & 13. 12.72 & Gastric ulcer $/ 2 / 2$ resection $+B$ II & 0 & 0 & 0 & - & 0 \\
\hline 7 & W.K. & $\hat{0}$ & 1.12 .72 & Acute pancreatitis/resection & 0 & 0 & 0 & - & 0 \\
\hline 8 & K.H. & $\hat{o}$ & 2. 12.72 & Acute pancreatitis/resection & 0.7 & 0.7 & 2.6 & - & $1.5^{2}$ \\
\hline 9 & A.S. & $0^{*}$ & 8. 12.72 & Pancreatic cyst/pancreatectomy & 1.3 & 1.6 & 1.9 & - & $2.6^{\mathrm{a}}$ \\
\hline 10 & A.F. & $\hat{\sigma}$ & 4. 4.72 & Cholelithiasis/cholecystectomy & 0.3 & 0.5 & 0.5 & - & 0.3 \\
\hline 11 & G.H. & $\hat{0}$ & 27. 4.72 & $\begin{array}{l}\text { Biliary obstruction by stones/ } \\
\text { revision of the bile ducts }\end{array}$ & 0.5 & 0.6 & 0.5 & 0.5 & - \\
\hline 12 & D.M. & q & 22. 6.72 & Cholelithiasis/cholecystectomy & 0.6 & 0.8 & 0.7 & 0.7 & $\ldots$ \\
\hline 13 & J.H. & $q$ & 26. 6.72 & $\mathrm{Ca}$ of the coecum/intestinal resection & 0.6 & 0.6 & 0.4 & 1.0 & - \\
\hline 14 & K.W. & $\hat{\delta}$ & 6.12 .72 & $\begin{array}{c}\mathrm{Ca} \text { of the papilla/biliary-digestive } \\
\text { anastomosis }\end{array}$ & 0 & 0 & 0 & - & 0 \\
\hline 15 & N.A. & 우 & 6.12 .72 & Perforated appendicitis/appendectomy & 0 & 1.5 & 0 & - & $0^{\mathbf{a}}$ \\
\hline 16 & S.N. & 安 & 22. 6.72 & $\mathrm{Ca}$ of rectum/intestinal resection & 0.6 & 1.4 & 0.9 & 1.3 & -a \\
\hline 17 & G.K. & $\hat{3}$ & 4. 4.72 & Struma/strumectomy & 0.4 & 0.4 & 0.4 & - & 0.3 \\
\hline 18 & H.H. & 우 & 29.6 .72 & Struma/strumectomy & 0.8 & 0.6 & 0.7 & 0.7 & - \\
\hline 19 & M.A. & 웅 & 2. 5.72 & Bronchial cancer/pneumoresection & 0.6 & 0.7 & 0.7 & 0.6 & - \\
\hline 20 & P.H. & $\hat{0}$ & 27. 6.72 & Bronchial cancer/pneumoresection & 0.3 & 0.8 & 0.6 & 一 & 0.6 \\
\hline 21 & G.E. & 우 & 27. 3.72 & Leg thrombosis/thrombectomy & 0.4 & 0.5 & 0.4 & - & 0.6 \\
\hline 22 & S.E. & 우 & 3. 5.72 & Leg thrombosis/thrombectomy & 0.5 & 0.2 & 0.4 & 0.8 & - \\
\hline
\end{tabular}

The age of the patients was $28-67$ years. No significant correlation could be shown between elevated plasma histamine levels and age. For further conditions see text under Results and Methods.

a Significantly elevated plasma histamine Ievels as defined in Methods. 20 hrs after the end of the operation means always the morning of the first postoperative day the end of operation being approximately at noon. 
Table 3. Influence of introduction of anaesthesia and of manipulations at the stomach and gut during abdominal operations on the plasma histamine concentrations in monkeys, pigs and dogs

\begin{tabular}{|c|c|c|c|c|c|c|c|c|}
\hline \multirow{3}{*}{$\begin{array}{l}\text { Animal } \\
\text { No. }\end{array}$} & \multicolumn{8}{|c|}{ Plasma histamine concentration $[\mathrm{ng} / \mathrm{ml}]$} \\
\hline & \multicolumn{3}{|l|}{ Monkey } & \multicolumn{2}{|l|}{$\underline{\text { Pig }}$} & \multicolumn{3}{|l|}{ Dog } \\
\hline & $5 \min$ & $30 \min$ & $60 \mathrm{~min}$ & $5 \min$ & $81 \pm 10 \mathrm{~min}$ & $5 \min$ & $30 \mathrm{~min}$ & $60 \mathrm{~min}$ \\
\hline 1 & 0 & 0 & 0 & 27 & 13 & 1.1 & 0.4 & 0.5 \\
\hline 2 & 1.2 & 0.6 & 0 & 43 & 16 & 0.9 & 0.8 & 0.6 \\
\hline 3 & 1.1 & 0.3 & 0.3 & 38 & 15 & 1.4 & 1.6 & 1.0 \\
\hline 4 & 1.8 & 1.2 & 0.6 & 22 & 13 & 1.1 & 0.8 & 0.2 \\
\hline 5 & 1.1 & 1.1 & 0.6 & 21 & 18 & 0.8 & 1.0 & 0.3 \\
\hline 6 & 1.8 & 0.6 & 0.6 & 28 & 15 & 1.1 & 0.4 & 0.5 \\
\hline 7 & - & - & $\cdots$ & 22 & 6 & 0.5 & 0.5 & 0.2 \\
\hline 8 & - & - & $\cdots$ & - & - & 0.8 & 0.8 & 0.4 \\
\hline 9 & - & - & - & 一 & $一$ & 0.6 & 0.6 & 0.3 \\
\hline $\bar{x} \pm$ S.D. & $1.2 \pm 0.7$ & $0.6 \pm 0.5$ & $0.4 \pm 0.3^{\mathrm{a}}$ & $29 \pm 8$ & $14 \pm 4^{b}$ & $0.9 \pm 0.3$ & $0.8 \pm 0.4$ & $0.4 \pm 0.3^{\mathrm{c}}$ \\
\hline
\end{tabular}

The operations in the animals are described in Methods. 5 min =immediately after introduction of intravenous anaesthesia, $30 \mathrm{~min}=$ after the end of the operation, and $60 \mathrm{~min}=$ after an interval of $30 \mathrm{~min}$ following the end of operation. In pigs, $81 \pm 10$ min means the beginning of the by-pass phase, in the recipient of a transplanted liver.

$a^{\text {a }} p 5 / 60<0.02$; $^{\mathrm{b}} p<0.005$; $^{\mathrm{c}} p 5 / 60<0.001$ (Student's $t$-test for paired data).

For further conditions see Materials and Methods.

perimental surgery were investigated (Table 1). Gastro-intestinal tissues and the lungs were especially rich in histamine, the highest concentrations being found in the small intestine of pigs and in the lungs of monkeys.

Histamine release from these tissues even being small on a percentage basis can produce histamine outputs of several $\mathrm{mg}$ the strong effects of which on the circulation are well known from pharmacological experiments.

Histamine concentrations in plasma and whole blood of human subjects and experimental animals were studied before, during and after operations. In 6 of 22 patients, elevated plasma histamine levels were observed following surgical treatment (Table 2). The point in time of maximum increase in plasma histamine was found to vary, but was within the first 4 hours after operation in 5 of 6 patients. In all these 6 individuals an abdominal operation had been performed, whereas the subjects being treated by a pulmonary resection showed no increase of plasma histamine concentration. Histamine in the whole blood was not altered significantly following surgery. In the same patients as described in Table 2 , the histamine concentrations before the operations were $0.086 \pm 0.020 \mu \mathrm{g} / \mathrm{ml}$, few minutes after the operation $0.087 \pm 0.019 \mu \mathrm{g} / \mathrm{ml}, 4,8$ and 20 hours later $0.083 \pm$ $0.022,0.078 \pm 0.014$, and $0.096 \pm 0.026 \mu \mathrm{g} / \mathrm{ml}$. So, the determination of histamine in whole blood was not a suitable method for evaluating histamine release in man in the course of operations.

In laboratory animals elevated plasma histamine concentrations were also found during and after standardized operations including cautions manipulations on the gut which were necessary to insert catheters in to a mesenteric vein (dogs and pigs) (Table 3). $30 \mathrm{~min}$ following the end of the mani- pulations, value had usually turned to normal. Thus, in animal experiments, at least half an hour after the preparation has to elapse before approximately basal conditions are reached. Since, however, the highest plasma histamine levels were determined immediately following the introduction of anaesthesia, studies were performed on histamine release following the administration of narcotic and hypnotic drugs.

\section{Causes for Histamine Release in Surgery}

Premedication by Atropine. The influence of atropine $(0.01 \mathrm{mg} / \mathrm{kg}$ i.v.) on the plasma histamine levels in man was investigated in 36 patients and test persons. 6 subjects showed elevated plasma histamine concentrations 1 and 5 min following the injection of the drug the increase being $150 \%$ (from $0.6 \pm 0.5$ to $1.5 \pm 0.5 \mathrm{ng} / \mathrm{ml}, p<0.02$ in the $t$-test on paired data). In the other 30 individuals, no significant alterations in the plasma histamine levels could be observed 1,5 and $10 \mathrm{~min}$ after atropine (before: $0.5 \pm 0.3 \mathrm{ng}$ histamine $/ \mathrm{ml}$ plasma, $5 \mathrm{~min}$ after the injection: $0.6 \pm 0.5 \mathrm{ng} / \mathrm{ml}$ ).

Intravenous Short-acting Anaesthetics. Following the injection of methohexitone, propanidid and Althesin CT $1341^{\circledR}$ histamine was released in some test persons (Fig. 1). Only Etomidate ${ }^{\circledR}$ never altered the plasma histamine levels. Cremophor ${ }^{\circledR}$ alone, the solubilizer both of propanidid and Althesin CT $1341{ }^{\circledR}$, as well as physiological saline as a control solution for methohexitone, did not increase the plasma histamine concentrations in the same test persons as used for the injection of the hypnotics.

Acute Blood Losses and Infusion of Plasma Substitutes. Neither in test persons nor in experimental animals did acute loss of blood cause a release of histamine within the time investigated. In human subjects, only about $1 / 10$ of the circulating blood 

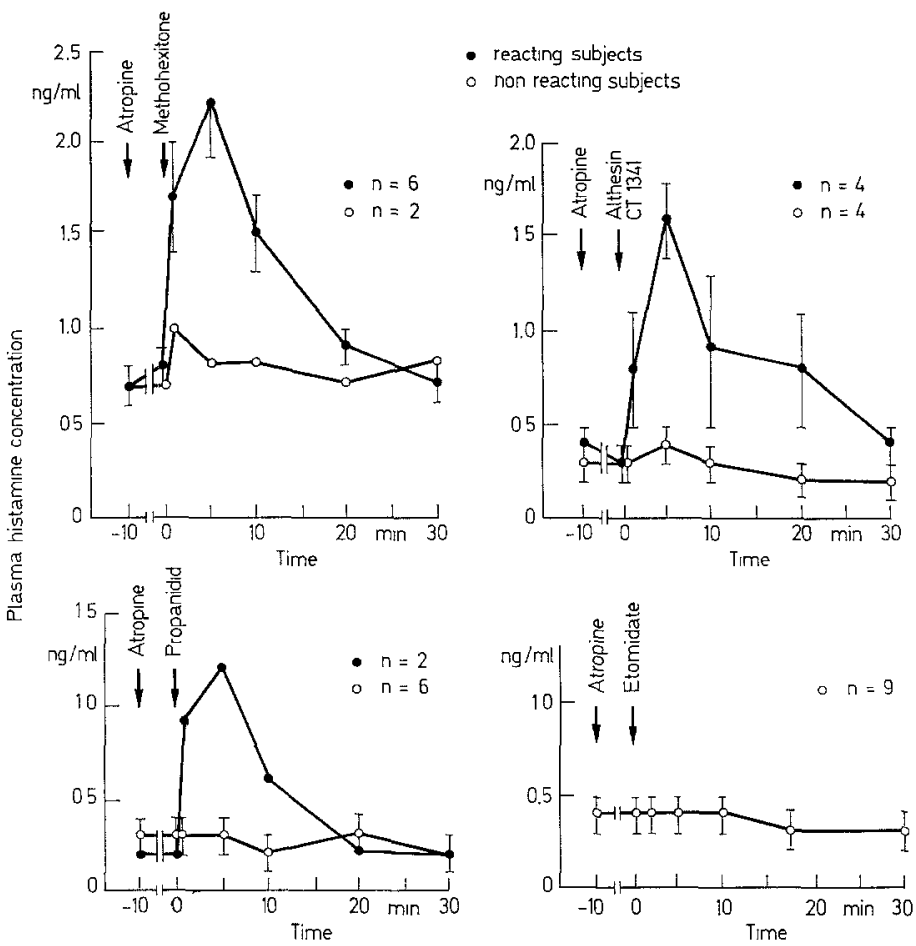

Fig. 1. Histamine release in several test persons following the injection of anaesthetic drugs. Mean values \pm S.E.M. The values from reacting and non reacting subjects were shown separately. The evidence for histamine release in a single test person was delivered by showing a type of climination curve for the plasma histamine concentration following the injection of the histamine liberator Bateman function. Statistical significance: Methohexitone $0 / 1 \mathrm{~min} p<0.025 ; 0 / 5 \mathrm{~min}$ $p<0.01 ; 0 / 10 \mathrm{~min} p<0.05$. Althesin CT $1341^{\circledR} 0 / 5 \mathrm{~min}<0.001, T$-test for paired data. For further conditions see Materials and Methods

Table 4. Incidence of histamine release and maximum increase of plasma histamine levels in man and several animals following rapid infusion of plasma substitutes

\begin{tabular}{|c|c|c|c|c|c|c|}
\hline \multirow[t]{2}{*}{ Species } & \multirow[t]{2}{*}{$\begin{array}{l}\text { Plasma } \\
\text { substitute }\end{array}$} & \multirow[t]{2}{*}{$\begin{array}{l}\text { Incidence } \\
{\left[n_{1} / n_{2}\right]}\end{array}$} & \multicolumn{2}{|c|}{$\begin{array}{l}\text { Plasma histamine concentration } \\
\text { (ng/ml] }\end{array}$} & \multirow[t]{2}{*}{$\begin{array}{l}\text { Increase } \\
{[\%]}\end{array}$} & \multirow[t]{2}{*}{$\begin{array}{l}\text { Signifi- } \\
\text { cance }\end{array}$} \\
\hline & & & $\begin{array}{l}\text { Before } \\
\text { infusion }\end{array}$ & $\begin{array}{l}1-10 \text { min } \\
\text { after infusion }\end{array}$ & & \\
\hline Man & $\begin{array}{l}\text { Dextran } \\
\text { Gelatin } \\
\text { Ringer }\end{array}$ & $\begin{array}{r}6 / 15 \\
10 / 12 \\
0 / 12\end{array}$ & $\begin{array}{l}0.4 \pm 0.4 \\
0.8 \pm 0.3 \\
0.8 \pm 0.3\end{array}$ & $\begin{array}{l}2.0 \pm 0.6 \\
1.9 \pm 0.3 \\
0.6 \pm 0.3\end{array}$ & $\begin{array}{r}400 \\
-\quad 140\end{array}$ & $\begin{array}{l}p<0.01 \\
p<0.001 \\
\end{array}$ \\
\hline Monkey & Gelatin & $2 / 6$ & 0.2 & 3.0 & 1400 & 一 \\
\hline Pig & Dextran & $0 / 9$ & $16 \pm 7$ & $17 \pm 5$ & - & 一 \\
\hline Dog & $\begin{array}{l}\text { Dextran } \\
\text { Gelatin }\end{array}$ & $\begin{array}{l}0 / 10 \\
9 / 23\end{array}$ & $\begin{array}{l}0.2 \pm 0.2 \\
0.2 \pm 0.3\end{array}$ & $\begin{array}{r}0.1 \pm 0.2 \\
20.5 \pm 18.5\end{array}$ & $\overline{10} 100$ & $\overline{p<0.02}$ \\
\hline
\end{tabular}

Mean values \pm S.D. incidence of histamine release given in number of individuals reacting to the substances $\left[n_{\mathrm{I}}\right]$ per number of subjects tested $\left[n_{2}\right]$. The plasma histamine concentration is given only for reacting individuals. Non-reacting subjects showed only insignificant changes in plasma histamine following infusion. The preinfusion levels of plasma histamine were not significantly different in reacting and non-reacting subjects. For comments, definition of the batches, and further conditions see Materials and Methods.

volume was withdrawn, which may have been too weak a stimulus for inducing histamine release from the tissues, but in all of the animals studied as much as about $1 / 3$ of the blood volume was rapidly removed. In 16 test persons, the plasma histamine concentration before the blood donation was $0.2 \pm 0.2 \mathrm{ng} / \mathrm{ml}$, after the withdrawal of blood $0.1 \pm 0.1 \mathrm{ng} / \mathrm{ml}$ being not significantly different from zero in most of the cases.

The infusion of plasma substitutes induced histamine release both in human subjects and in animals (Table 4). In test persons, dextran and gelatin both showed the effect, but Ringer's solution did not. As 


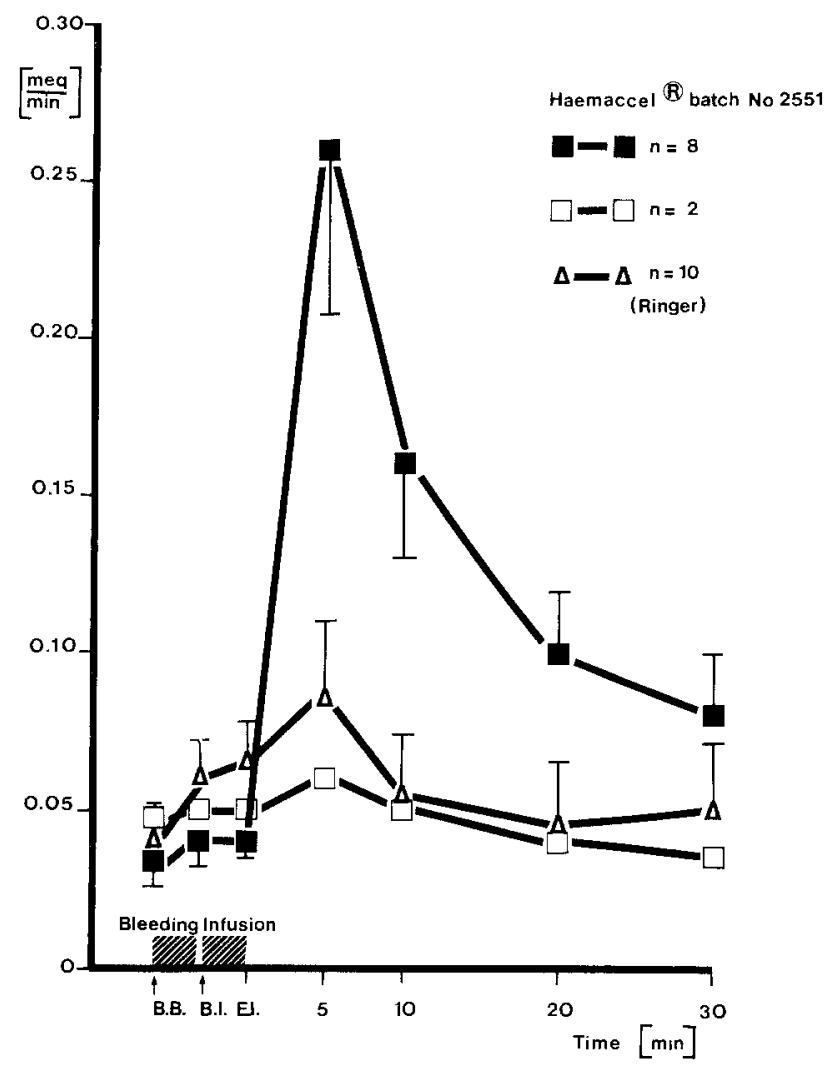

Fig. 2. Gastric acid secretion in test persons following rapid infusion of gelatin (batch 2551) and Ringer's solution. Mean values \pm S.E.M. The values from reacting and nonreacting subjects were shown separately. The same test persons as for the plasma histamine determinations were used (Table 4), gastric acid secretion and plasma histamine were determined simultaneously. However, in two test persons gastric acid secretion could not be measured for technical reasons, but only the plasma histamine levels. Statistical significance: Gelatin, reacting subjects $\mathrm{BI} / 5 \mathrm{~min} p<0.005, \mathrm{BI} / 30 \mathrm{~min} p<0.02$. $\mathrm{B} . \mathrm{B}=$ before bleeding, B.I $=$ before infusion, $\mathrm{E} . \mathrm{I}=$ end of infusion. For further conditions see Methods and Materials

in the case of the anaesthetics, the colloid and the control solution were administered in random order (digits of the Random Corporation, England). In dogs, gelatin was a very potent releaser of histamine in 9 of 23 animals, but dextran was without effect. Furthermore, gelatin elicited a small increase of the plasma histamine levels in 2 of 6 monkeys. Dextran was without effect in pigs. Thus, a relatively strong species specificity was observed regarding the histamine releasing activity of plasma substitutes, which has to be considered in the clinical evaluation of our results.

\section{Clinical Symptoms and Biological Reactions in the Course of Histamine Release during Operations}

At the time of elevated plasma histamine concentrations, no significant arterial hypotension could be observed in patients undergoing abdominal ope- rations. The injection of the narcotics, with the exception of Etomidate ${ }^{\circledR}$ sometimes caused a considerable hypotension lasting for $2-3$ minutes, but the reaction of the circulatory system neither quantitatively nor regarding to the course of time showed correlations with the plasma histamine levels (see also Lorenz et al., 1972). The infusion of plasma substitutes in test persons also did not alter the arterial blood pressure significantly.

In the 22 patients investigated no correlation could be demonstrated between alterations of the heart rate and changes in the plasma histamine concentrations. The tachycardia occurring regularly after the injection of the anaesthetics did not last longer than about $3 \mathrm{~min}$ being therefore not related to the histamine release. No changes in heart rate could be observed following the infusion of the plasma substitutes. However, in two test persons who showed an increase of the plasma histamine concentration up to $4 \mathrm{ng} / \mathrm{ml}$ following the infusion of gelatin, a slight tachycardia occurred which reached its maximum exactly at the time of the maximum increase of the plasma histamine concentration (increase in heart rate by 17 and 20 beats $/ \mathrm{min}$ ). These two test subjects also showed a oedematous swelling behind the ear and on the eye-lids as well as single wheals on the neck.

Gastric acid secretion was studied only in test persons receiving infusions of gelatin and Ringer's solution. Subjects who did not react to gelatin by a histamine release or were treated only by Ringer's solution showed no significant changes in gastric secretion (Fig. 2). However, the individuals, who reacted to gelatin by a histamine release, showed a stimulation of acid secretion parallel to the elevation of the plasma histamine levels. This reached half the maximal rate of acid secretion in some cases (Fig. 2).

In laboratory animals, no arterial hypotension following the infusion of plasma substitutes could be observed in monkeys and pigs. In dogs, however, a severe and in 2 cases letal hypotension occurred following infusion of gelatin in 9 of 23 animals. These dogs showed also an increase of the plasma histamine concentration.

\section{Discussion}

Histamine is known as a pharmacologically highly active substance: In human subjects, it stimulates gastric and salivary secretion, lowers the arterial blood pressure, causes tachycardia, increases the permeability of the vessels in the microcirculation and contracts the smooth muscles of the bronchi and the gastro-intestinal tract. The release of endogenous histamine, mainly from mast cells, induces the same biological reactions and subsequently the same clinical symptoms as being observed after the parenteral application of histamine. Only certain modifications in the pathophysiological reactions elicited by histamine can occur which must be taken into consideration, such as by the simultaneous release of other vasoactive 
substances from amine containing cells, especially the catecholamines, or by the region where the histamine release takes place (e.g. histamine from the gut does not or only partially overcome the liver's barrier).

Very different threshold doses or threshold concentrations of histamine in plasma are necessary to elicit different effects in the body. According to Lorenz et al. (1972), who produced increasing plasma histamine levels by infusion of increasing doses of histamine, the most sensitive reaction to histamine in man is the stimulation of gastric secretion $(1 \mathrm{ng} / \mathrm{ml})$, the second one tachycardia (4-6 $\mathrm{ng} / \mathrm{ml}$ plasma), whereas a significant hypotension can be measured only at plasma histamine concentrations of $6-10 \mathrm{ng} / \mathrm{ml}$. These findings explain, why the increase of the plasma histamine levels observed during the operations in this study only induced a stimulation of gastric acid secretion [see also Lorenz et al. (1969); Lorenz et al. (1972)].

Through severe or life-threatening elinical reactions to histamine release are not represented in this communication, the demonstration of histamine release during surgical operations seems to be clinically significant:

1. Normal human subjects react to anaesthesia and to the other treatments investigated in this study only by a small histamine release. However, in single cases and under various pathophysiological conditions such as sepsis, disturbances of the blood coagulation and fibrinolysis including the release of phosphatidyl serine, activation of the complement system by immunoglobulin aggregates or by the C3-activator system as well as sensitization, a massive histamine release occurred in patients (Lorenz et al., 1972), with the clinical symptoms of a severe anaphylactic or anaphylactoid reaction. Furthermore, such incidents have been repeatedly observed before, during and after operations, following the administration of atropine, propanidid, thiopentone, muscle relaxants and analgetics (for a survey see Lorenz et al., 1972 ) and also following the infusion of plasma substitutes (Lorenz et al., in preparation). Finally, severe clinical reactions (hypotension, cardiac arrest) complicated the course of liver transplantations which in certain phases of the operation could be attributed mainly to the occurrence of histamine in the circulation (Lorenz et al., 1973). It has not been sufficiently recognized that histamine release from the gastro-intestinal tract or from the liver is often not accompanied by skin reactions or by bronchospasm. So acute arterial hypotension in operations has seldom been attributed to histamine release.

2. Even in normal human subjects, the release of relatively small amounts of histamine, as determined in this study, may be of clinical significance. Increased gastric acid secretion despite of the injection of atropine (Lorenz et al. 1972) may be a cause of vomiting and aspiration as observed in one of our patients receiving propanidid (Doenicke, personal com- munication). Histamine release could have an importance in the development of postoperative stress ulcers (Seidel et al., 1973). According to Katz and Siegel (1968) a dose of exogenous histamine which elicites a nearly half-maximum gastric secretion is capable of causing haemorrhagic erosions in the human gastric mucosa. The plasma histamine levels, however, reached by such a dose of exogenous histamine (Lorenz et al., 1972), are very similar to those measured in the 6 patients included in Table 2. These results show that one cannot exclude the possibility endogenous histamine is involved in the formation of acute gastro-duodenal ulcers in human subjects.

Considering histamine release in surgery it is striking that medical treatments were responsible for increases of the plasma histamine concentration. The operation itself seemed usually to have much less effect. Also, extracorporeal blood circulation can cause histamine release as an undesired side-effect (MeyerBurgdorff et al., 1973).

\section{References}

Erspamer, V.: Participation of 5-hydroxytryptamine in physiopathological processes. Handbook of experimental pharmacology, p. 360. Berlin-Heidelberg-New York: Springer (1966)

Holtz, P., Palm, D.: Brenzkatechinamine and andere sympathicomimetische Amine. Reviews of physiology, biochemistry and experimental pharmacology, p. 263. BerlinHeidelberg-New York: Springer (1966)

Katz, D., Siegel, H. J.: Progr. Gastroenterol. 1, 67 (1968)

Lorenz, W., Barth, H., Kusche, J., Reimann, H.-J., Schmal, A., Matejka, E., Mathias, Chr., Hutzel, M., Werle, E.: Europ. J. Pharmacol. 14, 155 (1971)

Lorenz, W., Doenicke, A., Halbach, S., Krumey, I., Werle, E.: Klin. Wschr. 47, 154 (1969)

Lorenz, W., Doenicke, A., Meyer, R., Reimann, H.-J., Kusche, J., Barth, H., Geesing, H., Hutzel, M., Weissenbacher, B.: Europ. J. Pharmacol. 19, 180 (1972)

Lorenz, W., Doenicke, A., Meyer, R., Reimann, H.-J., Kusche, J., Barth, H., Geesing, H., Hutzel, M., Weissenbacher, B.: Brit. J. Anaesth. 44, 355 (1972a)

Lorenz, W., Hell, E., Boeckl, O., Reimann, H.-J., Zimmermann, G., Seidel, W., Laszcz, M., Uhlig, R., Europ. Surg. Res. 5, 11 (1973)

Lorenz, W., Matejka, E., Schmal, A., Seidel, W., Reimann, H.-J., Uhlig, R., Mann, G.: Comp. General Pharmacol. 4, $229(1973)$

Lorenz, W., Reimann, H.-J., Barth, H., Kusche, J., Meyer, R., Doenicke, A., Hutzel, M.: Hoppe-Seylers Z. physiol. Chem. 353, $911(1972 \mathrm{~b})$

Messmer, K., Lorenz, W., Sunder-Plassmann, L., Kloevekorn, W.-P., Hutzel, M.: Naunyn-Schmiedebergs Arch. Pharmacol. 267, 433 (1970)

Meyer-Burgdorff, C., Seidel, G., Schlüter, F.J.: Anaesthesist 22, $212(1973)$

Rocha e Silva, M.: Histamine. Its role in anaphylaxis and allergy. Springfield: Ch. C. Thomas

Schayer, R.W.: Chemotherapia 3, 129 (1961)

Seidel, W., Lorenz, W., Doenicke, A., Mann, G., Uhlig, R.: Brit. J. Surg. 60, 320 (1973)

Prof. Dr. W. Lorenz

Chirurg. Universitätsklinik

Abt. für Exper. Chirurgie

und Pathologische Biochemie

D-3550 Marburg a.d. Lahn

Robert-Koch-Straße 8

Federal Republic of Germany 